\title{
CHURCH EDUCATION IN RUSSIA
}

\author{
Bogdan Ershov', Galina Bykovskaya ${ }^{2}$, Irina Obertyaeva ${ }^{3}$ \\ ${ }^{1}$ Doctor of Historical Sciences, Professor, Voronezh State Technical University, 20 years of \\ October street, 84, Voronezh, Russia, E-mail: bogdan.ershov@yandex.ru \\ ${ }^{2}$ Doctor of Historical Sciences, Professor, Voronezh State University of Engineering \\ Technologies, Revolution Avenue,19, Voronezh, Russia, E-mail: istoria_vrn@mail.ru \\ ${ }^{3}$ Candidate of Historical Sciences, Associate Professor, Air Force Academy N.E. \\ Zhukovskogo and Y.A. Gagarina, Old Bolsheviks street, 54a, Voronezh, Russia, \\ E-mail: irina-obertyaeva@mail.ru
}

\begin{abstract}
The problem of professional church education in Russia today is of quite understandable interest. As you know, for a long time the Orthodox Church in Russia was an integral part of state and spiritual life, in this capacity it played a large, albeit ambiguously positive, role in the formation of many generations, in strengthening the socio-political order prevailing in the country. After October 1917, during the Soviet period, the Church was separated from the state and even in some respects from society; its role and place in the life of society were minimized, but did not go unnoticed.

In the context of profound historical changes that took place in Russian society at the turn of the 20th and 21 st centuries, the role of the Russian Orthodox Church has changed dramatically. More and more, the Church claims to be the bearer of the spiritual principle in society, one of the regulators of its spiritual life as a whole. Many today strive to create not only their personal lives, but also social activities based on the Orthodox worldview.
\end{abstract}

Keywords: society, religion, state, man.

\section{INTRODUCTION}

In modern conditions, when spiritual aggression towards our people is growing on the part of religious confessions conducting proselytizing activities on the canonical territory of the Russian Orthodox Church, there is a rapid growth of new religious movements in Russia itself and the expansion of various sects into its territory, the problem of professional church education acquires public importance. Since only theological educational institutions can provide those two-sided, spiritually and theologically trained cadres, without which the Church, with a rapidly filling it with a large percentage of spiritually inexperienced priests and monastics without special theological education, will steadily lose its authority, and as a result the people will be in power well-trained non-faith preachers and ideologists, under the influence of occult and neo-pagan influences, destructive sects. This directly follows from the fact that at the present moment the spiritual state of our society is on the verge of a shaky balance between Orthodoxy and any kind of other faith.

The modern era is a difficult time from a spiritual point of view. The difficulties of today are associated with the overwhelming desire of the younger generation to create and surround themselves with a kind of "new" culture, new moral and ethical values, completely different from everything previously known. It can be said without exaggeration that we live in an era of unprecedented spiritual freedom.

\section{METHODOLOGY}

The methodological basis of the research is a combination of general scientific and special historical methods of scientific research. The diversity of the material under study required their use in organic unity to identify the cause-and-effect pattern of events and phenomena, the important role of the subjective factor in 
history. The main methodological component was the comparative-evolutionary and comparative-historical analysis of the integral-systemic, concrete-historical process, which allowed the authors to compare the same features in comparison (increment or disappearance, narrowing), to identify the main trends and features of the historical process associated with the professional - the educational activities of the Church, to trace the connection between history and modernity, the cyclical recurrence of a number of characteristics of church-historical experience in the field of personnel training.

The study of the problem was carried out using general scientific principles: dialectics, scientific approach, historicism, consistency, complexity. First of all, the authors were guided by the scientific principle, as the main principle of general scientific analysis and historical and theoretical research of the topic.

\section{DISCUSSION}

The interaction of religion and society, which is closely related to the problems of religious education, is considered in the works of L. A. Andreeva, R. Bell, A S Vatoropin, M Weber, D Dewey, E Durkheim, A G Zdravomyslov, N. B. Kostina, I A Kunitsin, L. Levi-Bruhl, K Marx, K Manheim, S V Medvedko, R Merton, N. D Nikandrov, E D Rutkevich, M G Pismanik, P Sorokin, N Smelzer and etc.

The direct study of some aspects of religious education is currently being addressed by religious scholars and jurists V. I. Garadzha, Yu P Zuev, A. B. Kolodin, M. N. Kostikova, T. A. Kudrina, I. A. Kunitsin, L. N. Mitrokhin, F. G. Ovsienko, N. A. Trofimchuk, etc. Some aspects of religious education were in the field of view of the classics of world sociology M Weber, E. Durkheim, K. Manheim.

Institutional aspects of religion from the standpoint of structural and functional analysis were considered by well-known historians and sociologists R Bell, M Weber, E Durkheim, O. Comte, G Ladberg, K Levi-Strauss, B Malinovsky, A. Radcliffe-Brown, G Spencer, D. Homans.

The comparative method in the study of religious institutions was used by M Weber (comparison of" ideal types " of Protestantism and Catholicism institutions), E Durkheim (multivariate analysis of the stability of religious moral norms) This tradition can be attributed to such researchers as V. N. Nechipurenko, I. N. Polonsky, And Samygin, E Trench, B Wilson.

\section{RESULTS}

In order for the scientific and theological level of today's theological seminaries and academies to correspond to modern standards, cardinal qualitative changes are required in approaches to some aspects of the educational process, to methods of education. Determining the essence of the required changes, it is advisable to look at theological schools through the prism of historical experience, to compare their current situation with the one that existed in them before the revolution. In this regard, the experience of the past takes on special significance.

The study showed that, while the influence of the spiritual and moral life of society on the system of church education was decisive, it itself, in turn, had a strong impact on the cultural and ideological development of the country. A clear confirmation of this are numerous examples showing that the graduates of theological schools were preparing not only for the pastoral ministry. A considerable part of them was assigned to the civil service, taught. Some joined the ranks of the scientific and creative intelligentsia, worked in the field of state and social activities. This gives grounds to conclude that professional church education was one of the forms of human socialization.

The reforms of church education were dictated not so much by church as by state interests. The duality of the position of the bishops, in which, on the one hand, they were completely dependent on the chief prosecutor's office, and on the other, they completely ruled their diocese, inevitably affected their attitude to the issue of church educational reforms. Realizing their complete subordination to the secular authorities, the overwhelming majority of bishops were passive, hoping for a state initiative. As a result, their attention was mainly focused not on pastoral, but on political tasks. In this regard, it is easy to see that the church educational reforms did not sufficiently take into account the needs of the spiritual school itself, the originality of its national traditions, and, therefore, did not rely on them.

Under the influence of the state, the Church was "forced", in addition to its main sphere - the liturgical one to become more active in those of them that were closely associated with the preservation of autocracy, especially in the cultural and ideological one. To strengthen the Church and activate its role as the main instrument of state policy and the most important ideological institution of autocracy, it was necessary to raise the level of church education. Therefore, the transformation of theological schools was of national importance. 
The most characteristic tendency of reforms was manifested in the borrowing of secular models of education, which gave rise to some negative consequences. Experience has shown that the use of the appropriate order of the secular schools by the theological school led, in the main, to passive assimilation of the principles of the reforms of the secular school, which did not allow to develop their own, hindered the direct formulation of church educational tasks. In this aspect, the direction of church educational reforms as a selfdeveloping process from within as a result of overcoming one's own contradictions, on the basis of the development of national creative principles, was weakly, and in essence, was not implemented at all.

\section{v. CONCLUSION}

The fundamental shortcoming of theological educational institutions was the duality of the tasks they were solving. On the one hand, they were called to educate worthy candidates for the pastoral ministry, and on the other, to provide a general education for the children of the clergy, even though they were not disposed to church service. Hence the following disadvantages: lack of unity in the course of sciences; multidisciplinary subject requiring mechanical assimilation; lack of general education; the spiritual-estate character and, as a consequence of all this, the preparation for the ministry in the Church of persons who do not have any vocation to it, the closure of access for graduates of seminary to higher secular educational institutions. Such a situation led to the abandonment of "harmful elements" in the spiritual environment, who were angry with the Church for this injustice.

It should be emphasized that the general level of education of the clergy in all periods of historical development was extremely low, which was one of the main reasons for the ineffectiveness of his pastoral ministry.

In our opinion, the government's attempts to reform society in order to preserve and strengthen the autocratic power served as the main reason for the reformational transformations of the spiritual school in the period under review.

\section{REFERENCE LIST}

Atamanchuk G. V. (2002) the Essence of public service: history, theory, law, practice. 272 PP.

Baidenko V. I. (2004) the Bologna process: on the way to the Berlin conference (European analysis). M.S. Pp. 412-413.

Biryukov A. B. (2006) Internationalization of Russian higher education. №. 10. Pp. 32-47.

Ershov B. A., Semenkova E. V. (2016) The consequences of the collapse of the Soviet Union. International Journal of Humanities and Natural Sciences. № 3. Pp. 20-22. (in Russ).

Ershov B.A. (2010) The Russian Orthodox Church and secular power in the Voronezh province in the XIX early XX centuries. GOU VPO "Voronezh State Technical University". Voronezh. 167 p.

Ershov B.A. (2010) The system of spiritual education in Voronezh province in the 19th century. Education and Society. №. 5 (64). Pp. 105-108.

Ershov B.A., Fursov V.N. (2018) The Russian Church in the State Mechanism of Russia. Bulletin SocialEconomic and Humanitarian Research. № 1. Pp. 32-37.

Ershov B.A., Perevozchikova L.S., Romanova E.V. (2019) Globalization and Intensification of Spiritual Values in Russia in the Philosophical Aspect. 6th International Conference on Education and Social Sciences Abstracts \& Proceedings. Pp. 208-212.

Ershov B.A., Volkova E.A., Frolova E.V., Volkov N.M., Pletnev V.I. (2019) The Revolution of 1905-1907. in Russia: results and consequences. 6th International Conference on Education and Social Sciences. Abstracts \& Proceedings. Pp. 213-220. (in Engl).

Kazarenkova T. B. (2005) Education through life. Sociological research, №. 5. Pp. 146-152.

Korotkoe R. V. (2004) Problems of efficiency of higher education in the Russian Federation. Institute of Economics of the Russian Academy of Sciences. Center for labor market research and social processes, Moscow: Logos. 120 p.

Pronina E. I., Kolesnikova, E. Y. (2002) Activization of research in the field of sociology of education. 
Sociological research. №. 1. Pp. 141-143.

Romanova E.V., Perevozchikova L.S., Ershov B.A. (2017) The Lifestyle of the Human Being in the Information Society. 3rd International Conference on Advances in Education and Social Sciences Proceedings of ADVED Pp. 950-954.

Savelyev A. Y. (2003) higher education Reforms and their effectiveness. (1991-2000), Moscow: NIEVO. 87 p.

Smorgunov L. V. (2001) Humanitarian technologies and political process in Russia. St. Petersburg: publishing house of St. Petersburg.UN-TA. $224 \mathrm{p}$.

Sorokina N. D. (2001) the problem of the relationship between education and social differentiation in foreign sociology. Bulletin of Moscow state University. №. 2, Pp. 8-14.

Vyazemsky E. E. (2004) National-regional component of historical education. Moscow: Prosveshchenie. 157 p. 